\title{
A Study of Iran's Situation and That of Its Rival Countries in the Regional Equation
}

\section{Fatemeh Mehrdadi}

Department of Psychology, Kerman Branch, Islamic Azad University, Kerman, Iran

E-mail: faribaolia@yahoo.com

Jahanbakhsh Moradi

Department of Psychology, Kerman Branch, Islamic Azad University, Kerman, Iran

E-mail:faribaolia@yahoo.com

\author{
Doi:10.5901/mjss.2016.v7n3s3p364
}

\begin{abstract}
The present writing examines Iran's situation and that of its rival countries in the regional equations. In this direction the main question has been put forward and that is that what is the effect of regional equations on Iran's and the rival countries situation? As an answer the hypothesis has been put forward that regional equations has paved the ground for elevating Iran's situation and weakening its rival countries. The kind of the research method used is descriptive-analytical. Also in order to theoretically support the issue we have used the realist, neo-realist, defensive and offensive realist theories. Generally because of big changes like Islamic awakening The Palestinian issue, the big domestic changes in Lebanon, Iraq, Syria and Afghanistan crises the Middle East has experienced many crises. This issue has increased tensions and the existing divergence between Iran and the other regional and trans-regional rival powers. As a result the existing crises has become more complicated and the path is paved for vast insecurities.
\end{abstract}

Keywords: Iran, rival countries, the Middle east, crisis, regional equations

\section{Introduction}

The essence of the international system in today's world is as such that as much as the ranges of the role, penetration and the national interests of the powers increases to the same extent the necessity for widening the cooperation and the need for coalitions and concentration on regionalism increases. The Middle East which is one of the most important areas of the Islamic Republic of Iran's foreign policy and that of its rivals including Saudi Arabia, Turkey, the US. Israel and has always been very significant for the government bureaucrats of these countries. In this direction the big changes related to Iraq and Afghanistan, the issue of Palestine and Lebanon, the security of the Persian Gulf, arguments concerning Islamic awakening have propelled the powerful regional and trans-regional countries to choose the Middle East as one of the most important centers of their foreign policy to be able to elevate their situation and status in the international system and also at regional levels.

After 2001 the Middle East region has been transformed to a new political and security system in which all the important regional players are competing to stabilize their new roles in the region. Iran also as an important regional power to stabilize its role has chosen a foreign policy in the direction of strengthening co operations and widening exchanges at the regional level, dealing with the people, creating new coalitions at the level of governments, supporting Shia movements and groups, fighting against trans-regional powers. In other words the active presence of Iran in regional scenes after 2003 as it stabilizes the country's political, security and economic roles in the region it increases the country's strategic significance in the international system arena. On the other hand it should be mentioned that choosing theses policies by the Islamic Republic of Iran has created a ground for the creation of sensitivities and sometimes vast confrontations by the country on one hand and its rival countries on the other. Here authorities and Western media call Iran the spring of Shia crescent and also the crescent of resistance. It seems that based on behavioral measures Iran is an independent regional player which does not believe in the architecture of the Middle East big changes according to the desire of trans-regional powers and believes that the trend of the region's big changes following the learning of Islamic awakening is going ahead in a direction suitable to the desire of the region's peoples. But not considering these regional powers some players such as the small country Qatar seek to give direction to the trend of the Middle East big changes and this should be examined. 
But some factors have increased the vagueness and complexity of Iran's situation and its rival countries in the regional equations. One of the most important of such factors is the existence of religious fanatic groups. These groups while making the region's security big changes more complicated have placed an impact on the strategies of the foreign policy of the region's countries. Also the different and conflicting role of the trans-regional countries and clearly the U.S. can be pointed out. Making opposite policies vis-a-vis the region's issues such as concerning the argument of Islamic awakening is one of the most important ambiguities which the region's countries are facing. On the other hand lack of stability in the decision-making of the regional powers such as Iran, Saudi Arabia, Turkey and concerning the most important regional big changes is among the other issues and unknowns of the argument of this research work. In this research through examining and analyzing the subject an effort will be made to answer the ambiguities referred to in above.

\section{The ne-realist theory (with an emphasis on the thoughts of Kenneth Waltz)}

Waltz has a materialistic view of international relations which has been criticized by structuralists and particularly Wendt and Ruggie. For him values and rules are not important and what matters is the distribution of materialistic capabilities. Separate from the social structure many factors cannot be examined which through that they have denotations. Waltz does not pay attention to cultural changes that led to the formation of new governmental system. One cannot consider individuals without their social definition as basic atomic units. It can be said that most of governments and government bureaucrats perform in a rational manner but there is a need here for a theory that says how interests and also identities (and rationality too) take shape. (Derakhshandeh 2010, p.41)

Waltz believes that the structure of the international system forces big powers to note exactly the balance of power. The anarchic structure of the international system forces governments seeking security to compete with each other relating to power; since power is the best means for survival. In classic realism human nature is the main cause of security and military competition among big powers; while in neo-realism anarchy plays this role.

In sum it can be said that based on Kenneth Waltz views the most important elements of neo-realism are as follows:

First in the trend concerning organization of regional balance governments are considered the most major actionmakers and players. This can be viewed as a reflection of the role of governments in organizing power and also in creation of balance among players which are involved in their national security issue.

Second realists and neo-realists believe that anarchy is a very important feature of the international system. This means that there is no stability and permanent balance. The most important of all imperious rules to control the countries behavior has not taken shape. No player can play the role of the focal force in the trend concerning international balance and security; thus all of the players will try to prepare the necessary grounds for producing power and defense for themselves.

Third as international politics and regional balance take shape in anarchical conditions it is natural that all governments seek to increase their security and power. This shows that regional balance without noting countries incentive and strategy for producing power will not be realized. Hence it seems natural that foreign policy of political units in the trend of regional balance be in the direction of increasing power and security.

Fourth organization of regional balance needs this that countries use various means to produce power. Defensive and security tactics are among the means that governments use to reach their goals.

Issues like power exhibition, an increase in power and generating credit to secure citation power are among matters that protect regional balance.

Considering the elements referred to we can reach this conclusion that the feature of the international system and particularly the formation of distribution of power is an appropriate model for examining countries foreign policy in the trend of regional balance. The necessities of regional balance makes it essential that players use their internal capacities to increase stability and balance in competitive, cooperative and confrontation situations. (mosalanejad, 2011, PP. 145146)

\section{Strategic features of the Middle East region}

One of the most comprehensive definitions of the Middle East has been offered by George Owen professor of history and the Middle East of Harvard University. He believes: the Middle East expression principally is a strategic concept that for the first time was used in relation to a region between the Persian Gulf and Pakistan. This expression in the Second World War period covered a vast region from Egypt to Iran and from Syria and Iraq to Sudan. That was controlled by the 
center protecting the interests of the Middle East in the continent. That center belonged to the U.S. and Britain and was managed by the two countries specialists in Egypt (Sayyed Sajadi and Kalansari 2007, p.13). On the other hand the Middle East region has features that are:

1-situation: the Middle East is located almost between 20 and 40 North degree, in a transferring region between a tropical weather and a medium weather width. This geographical land is a place that connects Africa, Asia and Europe and includes the most important waterways and sea transportation networks. The Gibraltar strait, the Suez Canal, Bab-elMandeb and the Hormuz strait are important waterways that control the entering ways to the U.S., Europe and Far-East. This region from a geostrategic view is a contact region between Euro-Asia and the marine world and in addition to this that these waterways are among the important global strategic regions they are a link between land and marine strategies. This particular feature led to this geographical domain having much importance in the geographical theories.

Of course it seems that it is necessary to note this point that the situation importance of the Middle East is not just because of its strategic standing. Although after the disintegration of the Soviet Union the geostrategic value of that standing and position has been reduced considering the change in the essence of power relationship in the international system which probably displaces soft policies based on economic power with tense ones based on military power the geo-political situation of the Middle East in this direction has experienced a big change and still this geographical limit has a value for the industrial world. Thus in the past as well as in the present situation a large segment of trans-regional dealing of this domain with big powers has been rooted in this situation (Ghalibaf, 2009, p.2).

2- Natural resources: Natural resources has been an important source of effectiveness in the Middle East. One of these resources is oil and the history of its discovery in the Middle East goes back to the $19^{\text {th }}$ century. But since the second half of the $20^{\text {th }}$ century when oil has been a center for fights and global and regional big changes it has played an important role relating to the Middle East issues. Concerning the Middle East region oil reserves different estimates have been offered. For example according to an estimate done by the British Petroleum firm there is a stark difference between the level of the Middle East crude oil reserves and the big part of this belongs to Persian Gulf countries and other regions. And from 1028 million barrels which is the known reserves of the world's crude oil at the end of 2006 the Middle east alone has 774 billion barrels of the latter's total reserves. Also according to an estimate of the firm referred to in above the level of gas reserves of the region is $5 / 40$ percent of the world's gas reserves and Iran, Qatar, Saudi Arabia and the United Arab Emirates with 974, 910, 240, 214 trillion square foot respectively have the second, third, fourth and fifth world's gas reserves after Russia.

The Islamic Republic of Iran having huge oil and gas reserves in the world and having long experience in the area of energy and a suitable geographical condition possessing 137 billion barrels (12 percent) of proven world's oil reserves and 974 trillion square foot of the latter's gas reserves has an especial place in the area of securing global energy. Actually Iran's situation particularly in the area of gas has more significance since on one hand gas has found an especial place in the strategy of consumers concerning energy security particularly with respect to Asian countries and on the other hand the country has the second world gas resources and a better geographical position in the West Asia region (Ashuri 1997, p.76).

After oil and gas water is the third natural resource which has had an impact on the region. This strategic matter on one hand is a factor that creates tension and divergence and on the other hand it can be a basis for mutual cooperation and agreement. As almost 80 percent of the Middle East lands due to little atmospheric falls is dry water has been one of the main factors that has placed an impact on friendships, rivalries and seeking adventures. Anyway many Middle East countries because of the growth of the population and stable water resources do not have enough water and specialists believe that in future concerning water resources Syria, Jordan, occupied Palestine and Lebanon in the area of Jordan River will have some fights.

It is predicted that insufficient water in the next 30 years will reach a level where even the citizens drinking water and their industrial and commercial needs will not be satisfied. The increase in population in the Middle East and the need for food, sanitation and other industrial and urban needs has intensified that. In sum huge oil and gas reserves and insufficient consumption water resources are the two major issues that create trans-regional and inside the region tensions. And while oil intensifies political tension between the region's countries and trans-regional powers insufficient water paves the ground for regional fights (Ibrahimi 2009, pp. 1-2).

3- Border lines: Usually in a natural and political manner borders can be divided and studied. A natural border points to endurance and homogeneity of the geographical condition of the internal land of a country vis-à-vis the lack of homogeneity relating to the condition of a neighboring land. Political borders are conventional ones and they distinguish political units from each other. If political borders match natural ones quality distinctions will be increased since in a natural way the endurance and the soil homogeneity of a country from its neighboring ones will be separated. If political borders do not match natural ones the border will not have a suitable quality. Most of the Middle East region's borders are 
of this kind. Actually in the 19th century in Asia in the part where Arabs lived from Anatolia to Egypt there were no borders. It is rare to find a country in the Middle East that does not have a border discord with its neighbor or its neighbors. For instance only among Persian Gulf countries as a segment of the Middle east there are more than 50 cases relating to border discord (Ashuri 1997, p.55).

4- Human factors: Middle East geo-politic has not only been effected by natural factors it has most importantly been influenced by dissimilar human factors. From a racial and cultural angle this region has been a place to various racial and cultural groups such as the cultures of Iranian, Arabic, Berber, Turk and Kurd and the people speak Farsi, Arabic, Turkish, Kurdish and Hebrew. Also most of the population of the Middle East countries is Muslim and almost 40 countries officially call themselves Muslim ones.

On the other hand almost 93 percent of the people of the Middle East and North Africa are Muslims and though Islam units the two regions they get separated by the two branches of Sunni and Shia. Actually among Muslim countries where most of the population is Sunni in the Middle East Iran and Iraq's population is mostly Shia and Lebanon and Bahrain because of the large Shia population Syria where Alavi Shias rule though they are a minority and the Shia group in Saudi Arabia because of living in areas where oil can be found place an impact on geo-politic big changes from the Persian Gulf to the Mediterranean.

The Middle East condition encompasses passing and a big change in the hierarchy of powers and the effort made by each power to shape the new system. On the other hand the new understanding of geo-politics believes that in the new situation the Middle East has issues and problems and the main axis here is security. Opposite to the traditional approach the new geo-politic gives us the understanding that beside natural competition the players in order to have a higher standing in the new hierarchical system are tied with one another because of numerous issues. This does not call for fighting and requires cooperation and partnership in shaping a system that is stable as it is competitive too (Vaezi 2009, P.5).

As the Middle East is the most international region in the world it is also one of the spots that has the most instability and crisis. The political life of most of the region's countries is marked by crises and political problems of other countries in there. Actually the countries regional foreign policy instead of seeking advancement of national interests outside of the borders should most of all through having a control-based approach watch for the entrance of factors from outside to the inside of national borders that create insecurity. On one hand the running into of national interests of the region's countries and on other hand the cohesiveness of the interests of big powers relating to regional issues has caused instability and tension inside region's big changes and that has been institutionalized also.

The existence of Israel and energy strategic resources in the region has had the most impact on the essence of the Middle East that creates tension. Iran can be influenced from its North and East. The disintegration of the Soviet Union in early 1990s while creating opportunities for the country increased regional threats and the grounds for the creation of crises in the country's peripheral regions (Vali Pour Zarumi 2004, pp. 470-471).

Change in the Middle East internal level creates results and reflections in the region that are like waves. The change in the ruling of Iran in 1978 had no opportunity for sending the revolution to the outside but after that the Soviet Union's military attack came about. This is true about the coming to power of Naser in Egypt, the change in ruling of Iraq from Hasan Albakr to saddam or even the change in political succession inside every country. This issue shows the cohesiveness of the Middle East countries issues. At this level this case almost cannot be observed in the world's other regions and on one hand this indicates the level of instability and the ground for change in the Middle East and on the other hand the existence of inappropriate domestic and regional order and the presence of outside powers in the region.

Iran as one of the regional players which from a cultural and economic aspect has comparatively much capability is making an effort to know the game rules that dominate the world order or to use its cultural and economic capability to increase its power and credibility in the international society. Of course this more than anything else depends on choosing realistic policies based on national interests and not trans-national policies that may challenge the dominant rules of the game, the global system and the axes players.

The Middle East from the regional power balance aspect is going through a passing period and this can create potential challenges for its security and stability. To go through this sensitive stage it is necessary to design and implement indigenous regional innovations to achieve stability and security since the experience of imposing transregional models and ignoring the role of regional influential powers has led to the defeat of them. It seems that the continuity of many of the existing security challenges in the Middle East is caused by the lack of existence of an indigenous comprehensive structure for security cooperation based on positive partnership of regional powers. The designing and creation of such a structure can through using the making of trust, signing of treaties dealing with rejection of invasion, peaceful resolution of regional fights and ultimately making the ground for increasing regional economic cooperation secure permanent security and stability in the Middle East. 


\section{The factors that pave the path for Iran's getting power in the region}

The trend of the region's big changes expresses this reality that Iran has turned into a better regional power meaning the first degree power of that; power and authority which even American and Western major personalities testify to it. Considering that Iran is the first Shia powerful rule and also considering the Islamic revolution's ideals and the acceptance of them by the region's Shias as a result the West in order to stop them has been involved in the Shia facing the Sunni. Thus among those who are Sunnis Shia is shown as being dangerous and among the Shias. It puts forward the extremism of the Sunnis. Actually the most major elements of Iran's power which has created a fear from the U.S. and its Western and Arab allies are as follows:

Iran's increasing penetration in the region and the world

Many capabilities that have various political, social. Cultural and security dimensions.

Technological and scientific capabilities (particularly fundamental steps taken concerning advanced technologies especially related to the fields of nanotechnology, basic cells and communication sciences).

Iran's military and defensive capabilities that has increased on one hand the deterrence power and the power to engage in reciprocal hits.

The increase in power and national strength given Iran's domestic political stability and the coherence of the internal power with the fundamentalist strategy or in other words the dominance of the latter's dialogue and justice as an axis and the quest for value.

Extraordinary atomic power which has been achieved given the possession of atomic fuel cycling.

The Islamic revolution's power to inspire and its influence on Islamic societies which has led to a wave of Islamic awakening and understanding in the region and the world particularly among Muslims and especially the region's countries. And the results of this influence may be mentioned as follows:

The victory of the Shias in Iraq and the coming to power of a Shia government.

The victory of the followers of Islam in Afghanistan's parliament.

The success of Ikhwan-ul-Muslimeen in Egypt's parliament.

The victory of Lebanon's Hezbollah in the 33 days war and an increase in the number of its followers in the country and the region.

The victory of Hamas in Palestine.

The current big changes in some of the countries of the Persian Gulf area particularly in Bahrain which is taking place and it is in the Shias interest.

An increase in the status of Iran in the region's security equations and elevation of the role and position of the country relating to resolving regional crises.

An active and smart role playing in diplomatic trends in the foreign policy arena and particularly regarding the atomic issue. (The power to use time and diplomatic opportunities)

The power to control or delete the U.S.'s plans and strategies such as the large Middle East plan, the path plan and other damaging plans in Lebanon, Syria, Iraq and Afghanistan

The collection of these issues has increased the trend relating to Iran's power

The steps taken by Iran's regional competitors to weaken the situation and penetration of that country in regional equations

\section{Fearing Iran}

The fear of Iran and thinking that it is a threat exists widely in the Middle East region governments and also in the world. Fearing Iran is caused by structural and non-structural factors. Power, geographical approximation and offensive power are among structural reasons for the structural fearing of Iran and offensive intentions and propagation of fearing Iran are among the non-structural reasons for that (Shariatinia 2010, p. 192).

Governments that achieve regional hegemony have another goal also and that is stopping the domination of other ones over other geographical areas. In other words regional hegemonic powers are not interested in having competitors that are equal to them and in fact they like to see that other regions are a scene for the competition of big and regional powers and are divided among them. The reaction of the U.S. vis-à-vis Iran's having more power can be explained in the framework of that kind of logic. Based on this from the view of theorists and those who design the U.S.'s policies and generally the West Iran is trying to dominate the Middle East and have hegemony in that region (Shariatinia 2010, p.194).

In this direction and based on this kind of logic Iran will particularly try to have a maximum gap between its power and that of its neighbors so that in the Middle East it will not be threatened by none of the governments. The non-stop effort made by Iran to have nuclear capability from the view of this kind of logic is ultimately designed to widen the gap between the country and its neighbors. Of course they admit that the trying to increase the power gap does not mean that 
Iran will go forward to attack and conquer its neighbors and actually it means that the country will dictate the limits of acceptable behavior to its neighbors (Tavangar 2009, p.28).

Fearing Iran as a reality has what effects on the country's international situation and national interests? The most important consequence of this reality is the shaping of a coalition against Iran in the region and trans-regional powers will manage that. The U.S. will act as the axis of the coalition and Arabs and Israel going along with that will shape the edges of that and will try to create balance vis-à-vis Iran. The U.S. has announced that its goal of transferring arms to its allies in the region and also giving strategic economic aids to them are in the direction of limiting Iran. In addition and from the angle of a hard military balance there is an intense arms race in the region with the goal of empowerment vis-à-vis Iran. Israel getting 13 percent and the United Arab Emirates getting 11 percent of the total sales of arms of the U.S. after South Korea (with 15 percent) are respectively the second and the third recipients of arms from the U.S. (Gerami, 2010, p. 52).

The effort made by the U.S. to minimize Iran's role:

The security threats of the U.S.'s direct military presence and its dangers are related to Iran's national interests. The U.S. uses all of its capabilities to minimize Iran's role in the region particularly in the Persian Gulf area in the direction of changing the structure of power and politics in Iraq and the coming to power of like-minded elites and supporters of creation of a coalition with traditional rules of the region against Iran. The U.S.'s strategic axes are: the creation of a direct linkage between Iran and terrorism in Iraq and trying to use the global anti-terrorism framework of laws and values to put pressure on Iran and putting forward the issue that that country is beside Al-Qaeda and suggesting these two as two major threats for the world security, creating a connection between Iran's policy in Lebanon and Iraq and reinforcing the belief in making Iraq like Lebanon by Tehran and linking Hezbollah's actions with Iraq's big changes, trying to distance Iraq's government from Iran and making a documentary to reinforce the idea of the damaging role of Iran in the region, limiting the choices of Iran's foreign policy in Iraq, encouraging Arab countries of the region to cooperate more with the U.S. in Iraq and reinforcing the worrying of the penetration of Iran in Iraq, encouragement of Iraq's Sunnis to cooperate more and getting regional support for the implementation of the U.S.'s Middle East policy, helping to intensify the disagreement over the Shia groups.

Eliott Cohen professor and the manager of the strategic studies section at John Hopkins university and the most neo-conservative face in academic circles in an article titled "The Fourth World War" in the proposed strategies to the American policy-makers puts forward this that Washington should support the free ruling that is modern and balanced in the Islamic world. The toppling and changing of Iran's regime has as much importance as the killing of Ben Laden because this is the only and the first revolutionary model among governments and the people and replacing it with a secular government which is also moderate is very important. The other issue is the domination and control of the U.S. over Iraq's oil that has increased its power in the international system compared to its European, Chinese and Japanese rivals to a large extent.

\section{Conclusion}

This research work is trying to examine Iran's situation and its rival countries in the regional equations. Thus considering the neo-realist theories it has explained the matter. Neo-realism that believes that government is the main player in the international political scene says that until the international system escapes from power the struggle relating to power and security will continue. Neo-realists believe that as the international system is anarchical countries seek to increase their power to have more security; hence helping the country is another feature of the international system meaning that countries should not wait for other governments assistance and help and actually should think about increasing their security. In this direction the Middle East is one of the regions of the world that has experienced most of the fights due to its strategic situation and the existence of huge energy resources in it. The Islamic Republic of Iran is one of the most important countries of this region and considering the neo-realist elements seeks to increase its power and security compared to its regional rivals.

Big security and political changes in the Middle East has led to Iran's re-defining and re-making its traditional diplomacy. A new, active and comprehensive diplomacy which covers all of the political, economical. Commercial security, military and information dimensions and aspects concerning regional and foreign policy relationships that is also related to trans-international and trans-land politics. The successful guiding and implementation of the new and comprehensive diplomacy in the Middle East requires improvement and changes in the structure, Shape. Manner and the means of that. These requirements that are of a shape, essence, structure and implementation nature may be expressed fully as follows:

1- Understanding the regional change and the big ones also

2- Getting to know its national interests and those of others 
3- Making good use of soft power

4- Multilateralism

5- Making trust

6- The role making of other ministries

7- Coordination among different policy makers

8- A developed human capital

9- Information-means development

10- Coordination of domestic and foreign policy

However after 2001 and the U.S.'s attack on Afghanistan and then in 2003 and the attack on Iraq the Middle East region's order faced a challenge. In the meantime Iraq had much importance for Iran. The scene of politics in Iraq is where the ideological and pragmatic aspects meet in foreign policy for the first time after the Islamic revolution. Contrary to the first decade of the Islamic revolution when ideological means influenced the goals of Iran's foreign policy this time that served the national interests and is the means for reaching national goals and security. The main reasoning is this that because of the quality and essence of the challenges and opportunities such as the engagement of all of the layers of the Iranian society and the dangers coming from security threats in the immediate security environment at the level of the neighbors the Islamic Republic of Iran ultimately should implement a degree of neo-realism in its foreign policy decision-making. In this framework making use of ideological means as one that creates opportunities may be considered the power point in the making of Iran's foreign policy. In other words the strengthening of the Shia element in Iran and Iraq relationship does not necessarily mean the strengthening of the ideological grounds. In fact that will be also assessed in the framework of the strategic goals and relations between the two countries.

\section{References}

Ashuri, Ali. 2007. The structural impediments to economic development in the Middle East. Master of Arts thesis, Tehran University: political science and law faculty

Derakhshandeh, Ali. 2010. Neo-realism and the security of the international system. Islamic culture quarterly. $2^{\text {nd }}$ year, number 1.

Gerami Mohsen. 2010. Fearing Iran, an examination of the role of the U.S. and Israel in the Middle East security strategies. Hekmat quarterly. Fourth year, number 12.

Ghalibaf, Mohammad Bagher. 2009. The Middle East, the new geo-politics and Iran and the U.S. challenges. Sabuh monthly. Number 14.

Ibrahimi, Hossein. 2009. Power and security in the world after September 11 $1^{\text {th }}$. Tabriz's Azad University quarterly, the new period, number 1

Mosalanejad, Abbas. 2011. An examination of the power balance policy of Iran in the realist and neo-realist approach. International relations researches. First period, number 1

Sayyed Sajadi, Mitra and Parveene Kalansari. 2007. What is the Middle East? View monthly. Number 5.

Shariatinia, Mohsen. 2010. Fearing Iran, reasons and the consequences. Foreign relations international quarterly. $2^{\text {nd }}$ year. Number 6

Tavangar, Ghasem. 2009. The confrontational approaches and the means of Iran and the U.S. after $11^{\text {th }}$ Septemeber. Imam Hossein University quarterly. $3^{\text {rd }}$ year. Number 7

Vaezi, Mahmoud. 2009. The Islamic Republic of Iran and the large Middle East plan. Zharfna quarterly, $10^{\text {th }}$ year, number 39.

Vali Pour Zarumi, Hossein. 2004. National security dialogues in the Islamic Republic of Iran. Tehran: strategic studies research institution 